Journal Of Al Azhar University Engineering Sector

Vol. 13, No. 46, January, 2018, 78-93

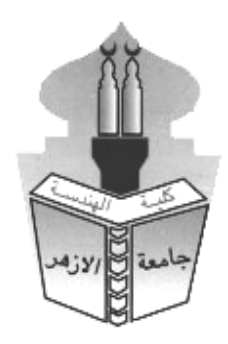

\title{
THE USE OF CARBON-NANOTUBES FOR REMOVAL OF BACTERIAL PATHOGENS FROM RIVER WATER
}

\author{
Hassaan, A. M. ${ }^{1}$, El-kady, M. A. ${ }^{2}$, Nasser, A. ${ }^{1}$, Etman, M. $^{3}$ and Omar, M. ${ }^{4}$ \\ ${ }^{1}$ Higher Technological Institute, $\mathrm{T}$ \\ enth of Ramadan City, Egypt. \\ ${ }^{2}$ Faculty of Engineering, Al Azhar University, Cairo, Egypt. \\ ${ }^{3}$ Pyramids higher institute, Egypt. \\ ${ }^{4}$ Faculty of Engineering, Misr University of Science and technology, Cairo, Egypt.
}

\begin{abstract}
Providing clean and affordable water to meet human needs is a grand challenge of the 21st century. Worldwide, water supply struggles to keep up with the fast growing demand, which is exacerbated by population growth, global climate change, and water quality deterioration. The need for technological innovation to enable integrated water management cannot be overstated. Nanotechnology holds great potential in advancing water and wastewater treatment to improve treatment efficiency as well as to augment water supply through safe use of unconventional water sources. Carbon nanotubes (CNTs) are microscopic, hollow, cylindrical tubes made out of graphene sheets. They contain several different, unique functions. Two functions in particular, mechanical and antimicrobial, cause nanotubes to be lethal to microbacteria, as well as being small, strong and flexible. This has allowed nanotubes to be produced as decontaminant filters.

The main objective of the present study is to develop a filter targeting the removal of microbial pathogens from river water. An experimental setup was constructed in which the multiwall carbon nanotubes (MWCNT) are used directly as a layer in the filter. The parameters investigated in the present work includes; the pressure, the temperature, the quantity of MWCNT utilized, and the thickness of MWCNT.

The present investigation reveals that the percentage reduction in total bacterial count, total coliforms count, fecal coliforms count and fecal streptococci count increases with the increase of the water temperature and larger thickness of CNTs. However, increase water pressure results in lower percentage reduction in total bacterial count, total coliforms count, fecal coliforms count and fecal streptococci count.
\end{abstract}

\section{INTRODUCTION}

Access to safe drinking water is a basic necessity for human life [1]. Water crisis is one of the greatest challenges of the present time. The lack of fresh and clean water is a ubiquitous problem around the world [2]. To address the undeniable need of pure water, various water treatment technologies have been proposed and applied at experimental and field levels. These technologies are commonly fall into primary (screening, filtration, centrifugation, separation, sedimentation, coagulation and flocculation); secondary (aerobic and anaerobic treatments); and tertiary (distillation, crystallization, evaporation, solvent extraction, oxidation, precipitation, ion 
exchange, reverse osmosis (RO), nanofiltration (NF), ultrafiltration (UF), microfiltration (MF), adsorption, electrolysis and electrodialysis) level water treatment technologies [3]. In recent years, nanotechnology has introduced different types of nanomaterials to water industry that can have promising outcomes. Since their discovery in 1991 [4], carbon nanotubes (CNTs) have attracted much attention in various scientific communities, with a myriad of applications in electronics, composite materials, fuel cells, sensors, optical devices, and biomedicine. Moreover, CNTs, because of their high surface area, electronic properties, and ease of functionalization, have excellent nanosorbent properties for filtering contaminants from water [5,6]. Previous studies in this field have focused on the use of bare CNTs or CNTs functionalized with inorganic nanoparticles for adsorption of inorganic contaminants and toxic metals from water [7-9]. Other studies have explored the use of CNTs for adsorption of low molecular weight organic contaminants [10] and toxins [11] from water.

In particular, CNTs have been studied as filters for the removal of viruses or bacteria. Singlewalled carbon nanotube (SWCNT) filters have shown high bacterial retention [12], and multiwalled carbon nanotube (MWCNT) filters have high viral removal efficiency at low pressure [13], both through the effects of size exclusion. Moreover, a SWCNT-MWCNT hybrid filter achieved efficient bacterial inactivation and viral retention at low pressure [14]. The application of an external electric field markedly enhanced the viral removal by the CNT filter, because of the increased viral particle transport [15]. Also, CNTs have been studied as filters for the removal of heavy metals and natural organic matter (NOM) [16-19]. Furthermore, in order to enhance the antibacterial ability of the CNT filter, vertically aligned MWCNT arrays were combined with silver nanoparticles [20,21], and CNT/cotton membrane was combined with silver nanowires [22]. A recent study demonstrated scalable applications of this technology that use low-cost and widely available CNTs for inactivation of microbes [23-25]. For viral removal by CNT-hybrid filters, filtration performance was also tested under various solution chemistries [26].These CNT-based filters remove the micrometer-sized bacterial cells through a sieving mechanism, whereas depth (physicochemical) filtration governs the adsorption of nanoscale viruses throughout the thickness of the matrix [27].

The present study aims at the use of CNTs as a sandwich layer in the filter as a method of raw water purification. The raw water samples are withdrawn from an urban natural stream. The removal of natural contaminants and suspended particles found in such stream is studied. Also the removal of any probable infectants as bacteria will be presented. The study parameters include temperature variation which was not presented in such survey. Also the amount of CNT filters is taken into consideration. The effect of pressure variation of the water inlet to the filter also will also be investigated.

\section{EXPERIMENTAL TECHNIQUE}

\subsection{Materials}

Multi-walled CNTs type was used in the process of water disinfection in the present study. Multi-walled CNTs (MWCNTs) with different functional groups were purchased from Cheap Tubes Inc. (Vermont, USA). To provide consistency among the CNTs under investigation, this study was restricted to this single commercial manufacturer. Important characteristics and unit costs (as reported by the manufacturer) of CNTs used in the experiments are shown in Table 1. According to the manufacturer, the pristine CNTs were prepared using chemical vapor deposition and further purified or functionalized using plasma methods.

The river water used in this study was obtained from Ismailia Canal. The collected water preserved at the room temperature in a clean plastic tank for use in subsequent test works.

Table 1 Characteristics of the used CNT:

\begin{tabular}{|l|l|l|l|l|l|}
\hline $\begin{array}{l}\text { Type of } \\
\text { CNT }\end{array}$ & $\begin{array}{l}\text { Outer diameter } \\
(\mathrm{nm})\end{array}$ & $\begin{array}{l}\text { Length } \\
(\mu \mathrm{m})\end{array}$ & $\begin{array}{l}\text { Specific surface area } \\
\left(\mathrm{m}^{2} / \mathrm{g}\right)\end{array}$ & $\begin{array}{l}\text { Purity } \\
(\mathrm{wt} \%)\end{array}$ & $\begin{array}{l}\text { Unit cost } \\
(\$ / \mathrm{g})\end{array}$ \\
\hline MWCNT & $20-40$ & $10-30$ & $>110$ & $>90$ & 0.45 \\
\hline
\end{tabular}




\subsection{GENERAL DESCRIPTION OF THE EXPERIMENTAL TEST-RIG}

The paraphernalia in figure (1) illustrates the setup of the laboratory-scale water treatment plant which is designed and constructed to be used to evaluate the use of CNTs as adsorption granular filter media. It is constructed mainly of two stages; the first stage consists of two tubes used for filtration process to get rid of any material or impurities found in raw river water which helps to keep CNT pipes longer in use. These tubes contain more than one element of the traditional elements that are used in water purification. The most common material used in water purification is sand. Sand of high quality has been used in this research. Active carbon is also used in the water purification process within the filter, and to remove odors. The tubes are filled with the same size and thickness of the sand layer (of fine sand and coarse grains) and the active carbon layer.

Another layer of materials that is used during the first stage of water purification is a layer of polypropylene (PP). This layer is located at the end of each tube so as to reserve both of sand and active carbon from coming out with filtered water, and also to improve the water purification process before it enters the second phase of disinfection.

The second stage of the laboratory-scale water treatment plant is the stage of disinfection. This stage contains a tube and there are two layers of PP material inside this tube between them the layer of CNT is put as a sandwich. This layer is responsible for retaining the bacteria from the water to make it safe for drinking.

A water heating system is employed in the present test rig to examine the effect of inlet water temperature on the purification process. The parameters considered in the present investigation include inlet water temperature and pressure, as well as CNT amount and thickness.

Samples were collected in one liter sterilized wide mouth glass bottles. These bottles were presterilized at $180^{\circ} \mathrm{C}$ for 30 minutes. Bottles were transported in sampling cooled box to the national research center to be examined within four hours form collection.

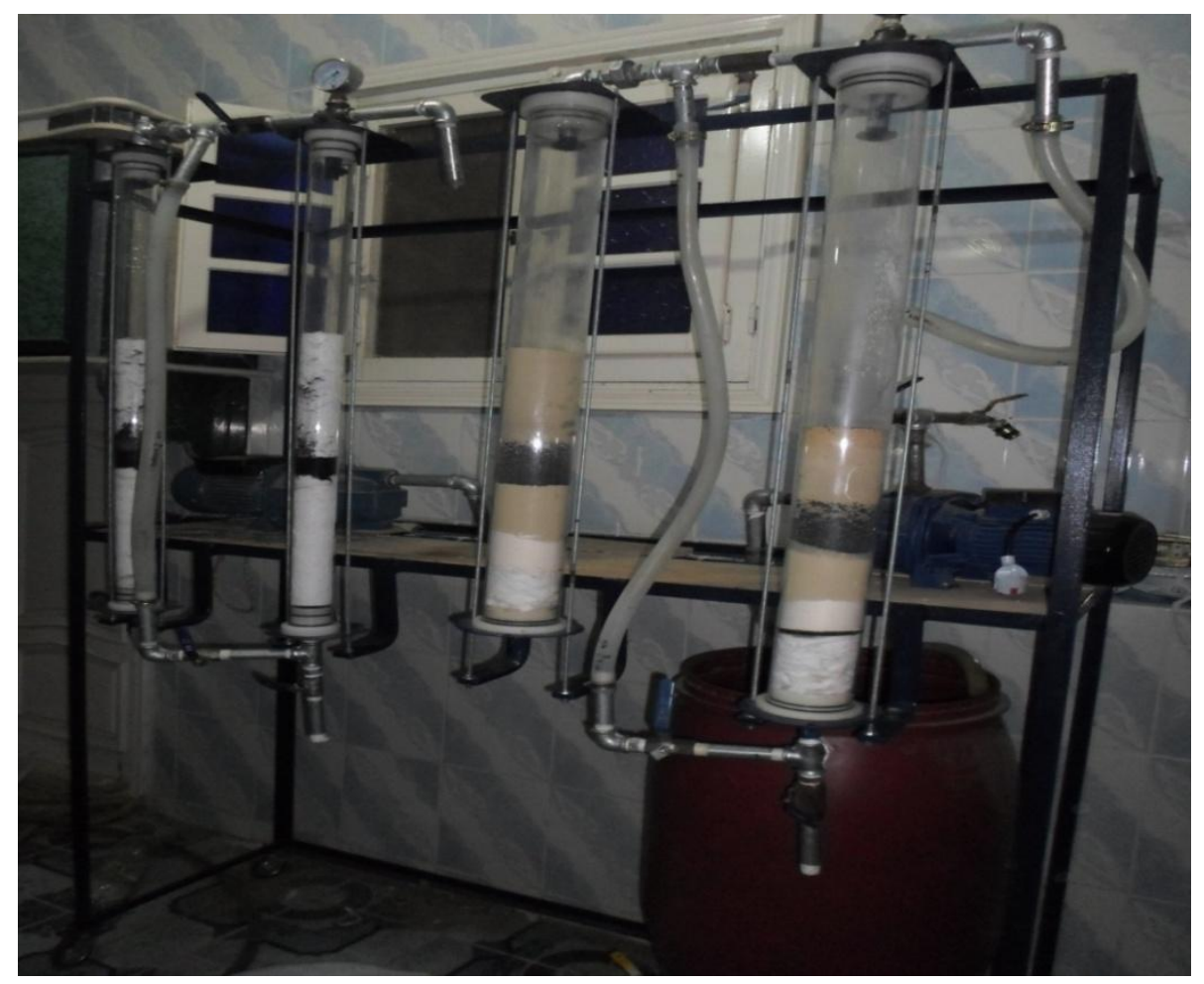

Figure (1) The Setup of the Laboratory-Scale Water Treatment Plant. 


\section{Results and Discussion}

The effect of water pressure, water temperature, thickness of carbon nanotubes (CNT), and the amount of the CNT, on the total bacterial count for samples at the human blood temperature $\left(37^{\circ} \mathrm{C}\right)$, and the average water temperature $\left(22^{\circ} \mathrm{C}\right)$, are investigated.

\subsection{Effect of the Water Pressure}

The variation of percentage reduction of total bacterial count per $1 \mathrm{ml}$ versus water pressure at two different temperatures $37{ }^{\circ} \mathrm{C}$ and $22{ }^{\circ} \mathrm{C}$ for the same inner diameter of $54 \mathrm{~mm}$ and different masses of carbon nanotubes is shown in the figures $(2 \mathrm{a}-2 \mathrm{c})$. It is observed that, a decrease of the percentage reduction in total bacterial count for the analysis at $37{ }^{\circ} \mathrm{C}$ and $22{ }^{\circ} \mathrm{C}$ is associated with the increase of water pressure. Raising water pressure may push water including bacteria through the CNT holes, however, the disinfection process is done by the retainment of the bacteria on the outer surface of the CNT. Therefore, the water pressure may force the bacteria approximating to the size of CNT holes to get out through the CNT hexagons holes.

It is also shown in the figures that, the percentage reduction in the total count of bacteria at the average water temperature $\left(22^{\circ} \mathrm{C}\right)$ is higher than that at the human blood temperature $\left(37^{\circ} \mathrm{C}\right)$. This can be explained as follows; the bacteria at $22{ }^{\circ} \mathrm{C}$ are weaker than the bacteria found at a temperature of $37{ }^{\circ} \mathrm{C}$, so if exposed to any external influence like a change in pressure or temperature or made reservation to it, the bacterial membrane may explode. Meanwhile, at a temperature of $37{ }^{\circ} \mathrm{C}$, the bacterial membrane may tend to vesiculation to resist any external effects.

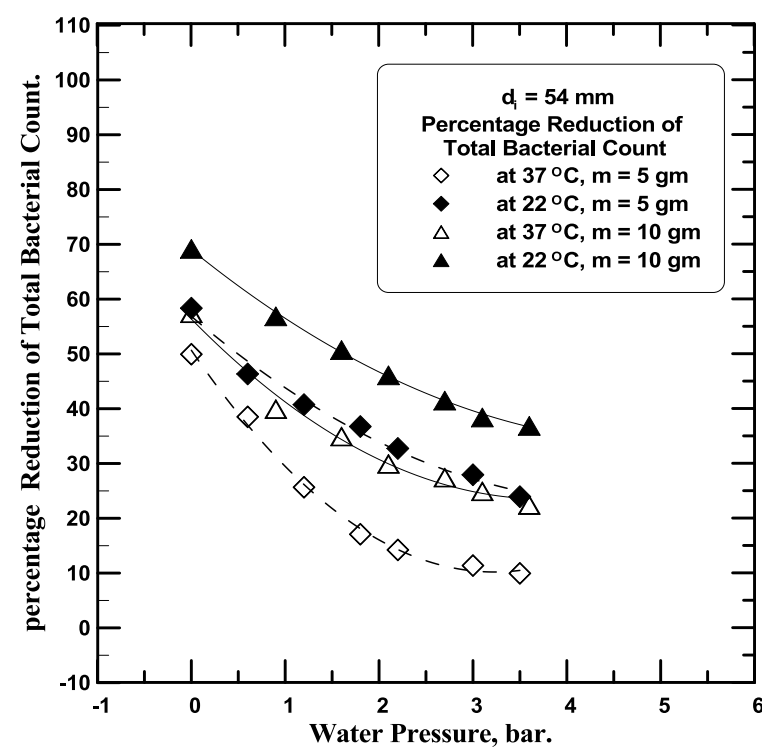

Figure (2a) Variation of Percentage Reduction of Total Bacterial Count with Water Pressure for Inner Tube Diameter $=54 \mathrm{~mm}$ and CNT mass $=5,10 \mathrm{gm}$. 


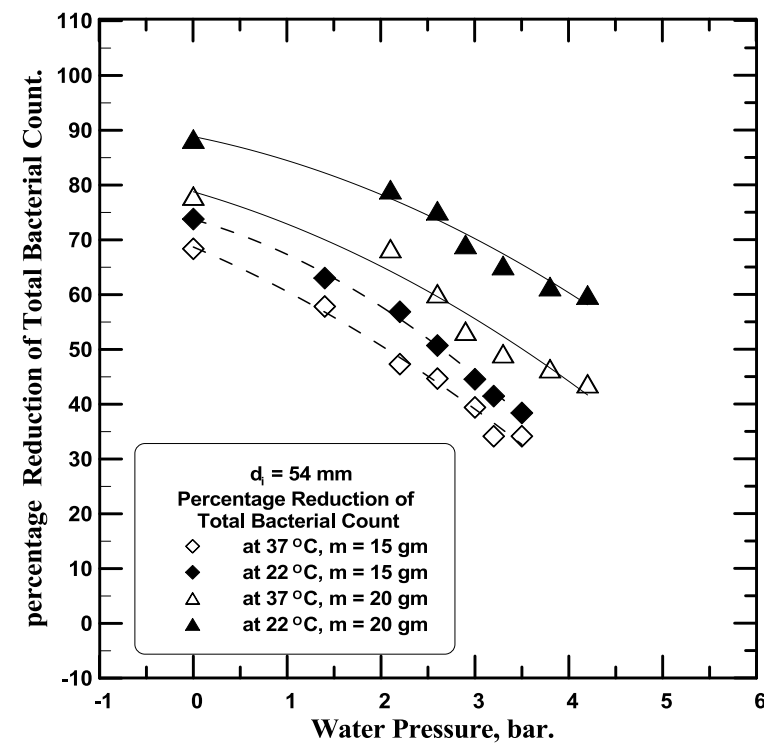

Figure (2b) Variation of Percentage Reduction of Total Bacterial Count with Water Pressure for Inner Tube Diameter $=54 \mathrm{~mm}$ and $\mathrm{CNT}$ mass $=15,20 \mathrm{gm}$.

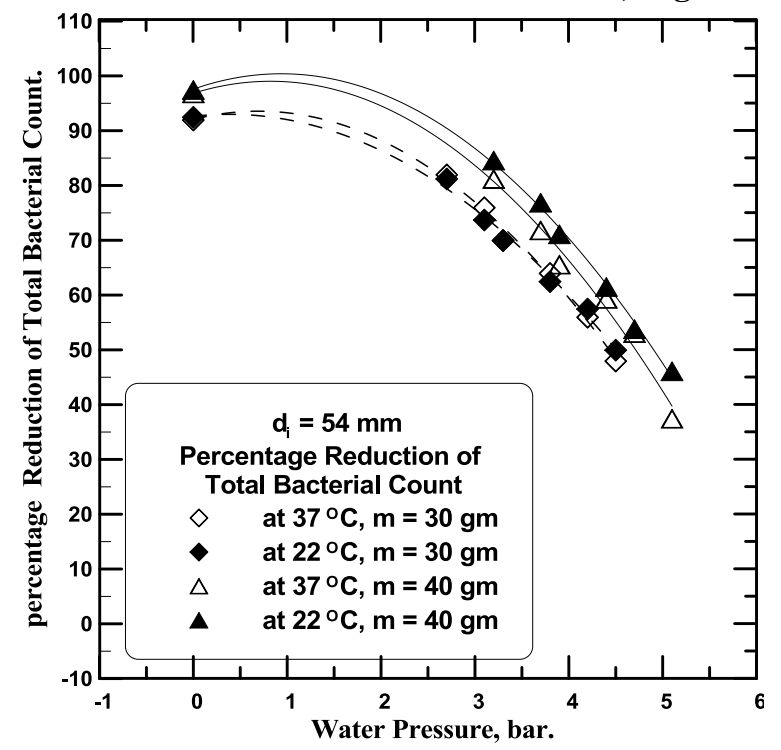

Figure (2c) Variation of Percentage Reduction of Total Bacterial Count with Water Pressure for Inner Tube Diameter $=54 \mathrm{~mm}$ and $\mathrm{CNT}$ mass $=30,40 \mathrm{gm}$.

The variation of percentage reduction of total coliforms count per $100 \mathrm{ml}$ versus water pressure for the same inner diameter of $54 \mathrm{~mm}$ and different masses of carbon nanotubes is shown in the figures $(3 a-3 c)$. It is also observed that increasing water pressure results in a decrease in the percentage reduction in total coliforms count. 


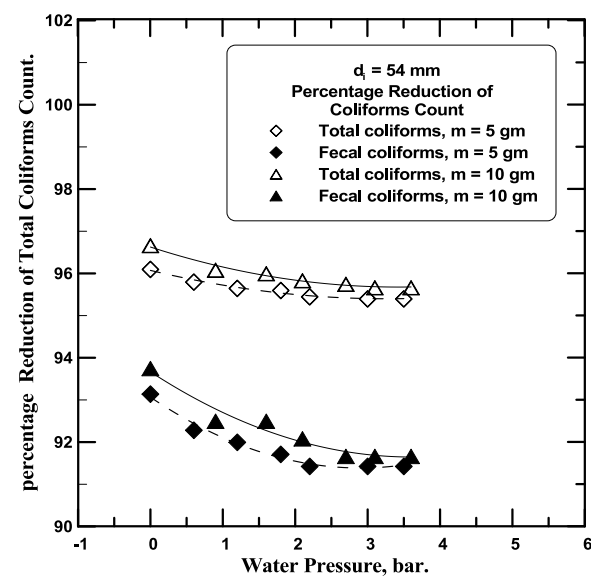

Figure (3a) Variation of Percentage Reduction of Total Coliforms Count with Water Pressure for Inner Tube Diameter $=54 \mathrm{~mm}$ and CNT mass $=5,10 \mathrm{gm}$.

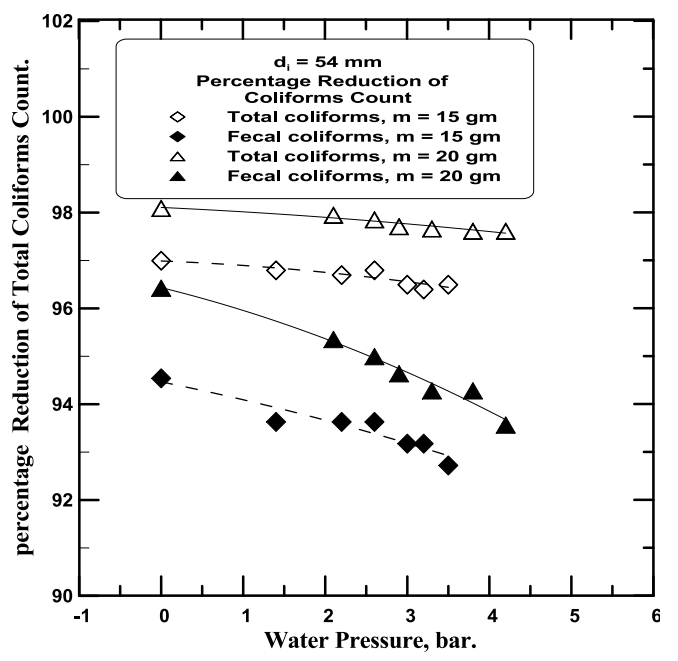

Figure (3b) Variation of Percentage Reduction of Total Coliforms Count with Water Pressure for Inner Tube Diameter $=54 \mathrm{~mm}$ and CNT mass $=15,20 \mathrm{gm}$.

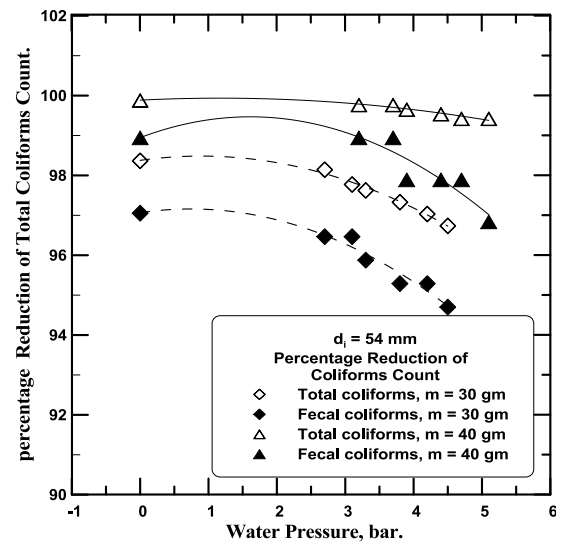

Figure (3c) Variation of Percentage Reduction of Total Coliforms Count with Water Pressure for Inner Tube Diameter $=54 \mathrm{~mm}$ and CNT mass $=30,40 \mathrm{gm}$. 
The variation of percentage reduction of fecal sterptococci count per $100 \mathrm{ml}$ versus water pressure for the same inner diameter of $54 \mathrm{~mm}$ and different masses of carbon nanotubes is shown in the figures $(4 a-4 b)$. It is noticed that, the percentage reduction in fecal sterptococci count decreases as the water pressure increases. The percentage reduction is higher if compared with the reduction of total coliforms count, this could be attributed to the spherical shape of these bacteria, and the nature of the outer surface shape of the tubes, which results in retaining larger amount of this bacteria.

\subsection{Effect of the CNT Thickness}

The variation of percentage reduction of total bacterial count per $1 \mathrm{ml}$ versus CNT thickness at two different temperatures $37{ }^{\circ} \mathrm{C}$ and $22{ }^{\circ} \mathrm{C}$ for the different masses $(20,40 \mathrm{gm})$ of carbon nanotubes for the case in which the water enters under gravity or pressurized with the minimum pressure needed to overcome the pressure drop through the CNT is shown in the figures (5a$5 b)$. As expected it is shown that, increasing CNT thickness yields an increase in the reduction of total bacterial count for both temperatures.

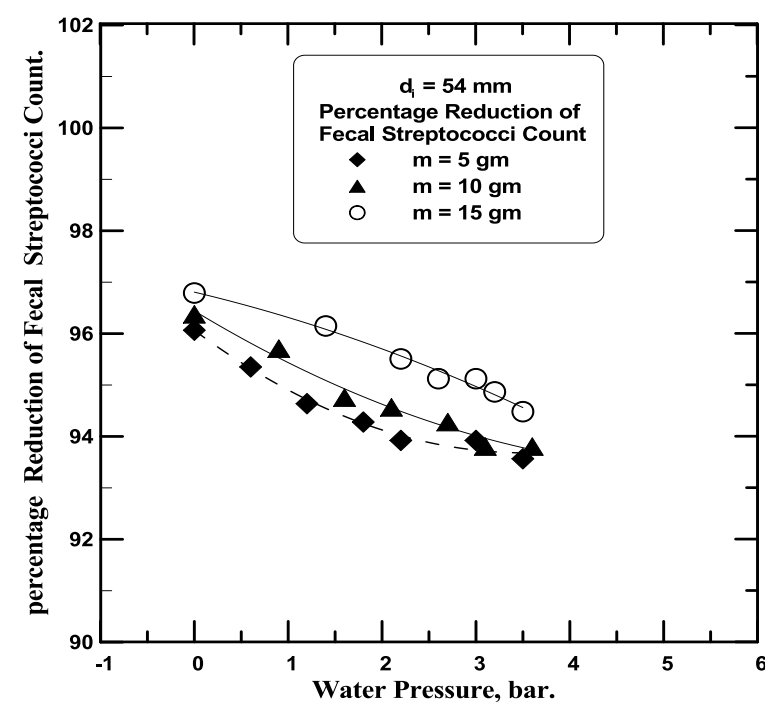

Figure (4a) Variation of Percentage Reduction of Fecal Streptococci Count with Water Pressure for Inner Tube Diameter $=54 \mathrm{~mm}$ and CNT mass $=5,10,15 \mathrm{gm}$.

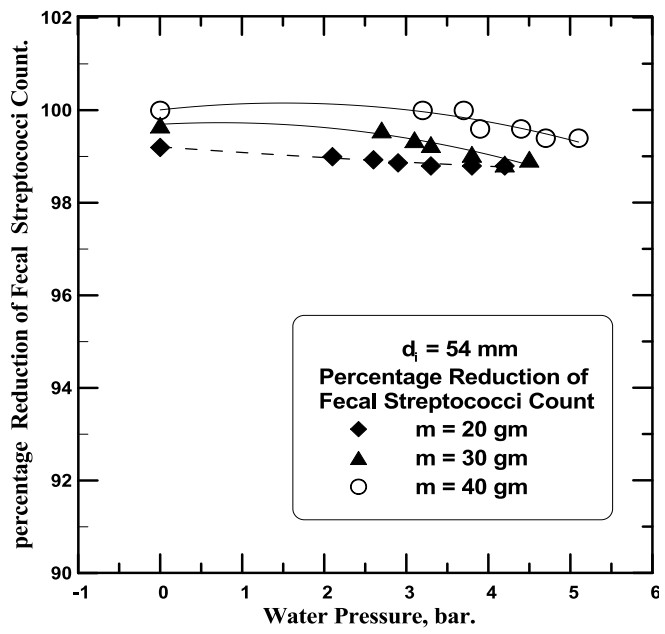

Figure (4a) Variation of Percentage Reduction of Fecal Streptococci Count with Water Pressure for Inner Tube Diameter $=54 \mathrm{~mm}$ and $\mathrm{CNT}$ mass $=20,30,40 \mathrm{gm}$. 
This may be explained as follows; the increase of CNT thickness causes the water to take longer time to pass througth the layer of the CNT which enhances the ability of carbon nanotubes to retain a large amount of bacteria from water.

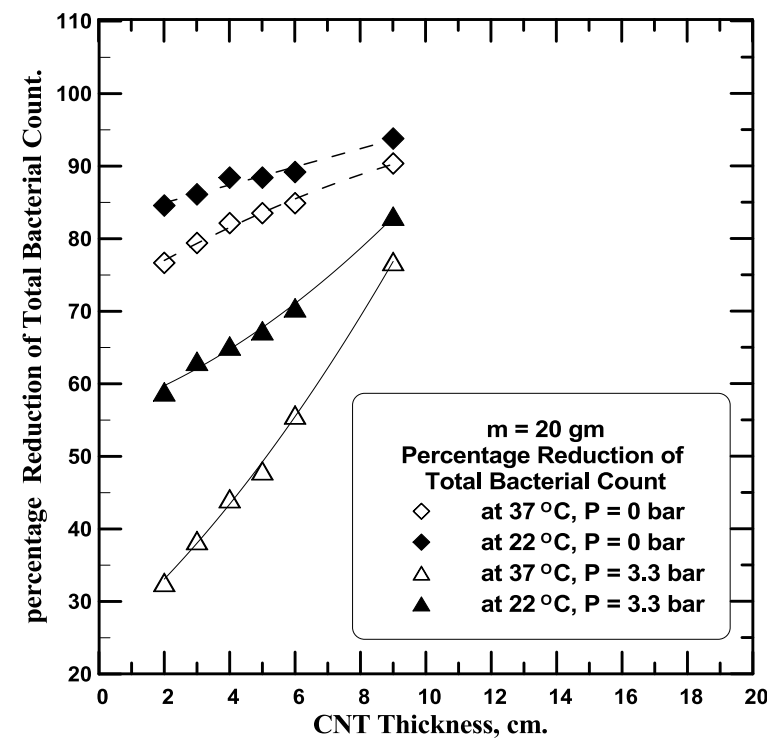

Figure (5a) Variation of Percentage Reduction of Total Bacterial Count with CNT Thickness for CNT mass = $20 \mathrm{gm}$ and Water Pressure 0, 3.3 bar.

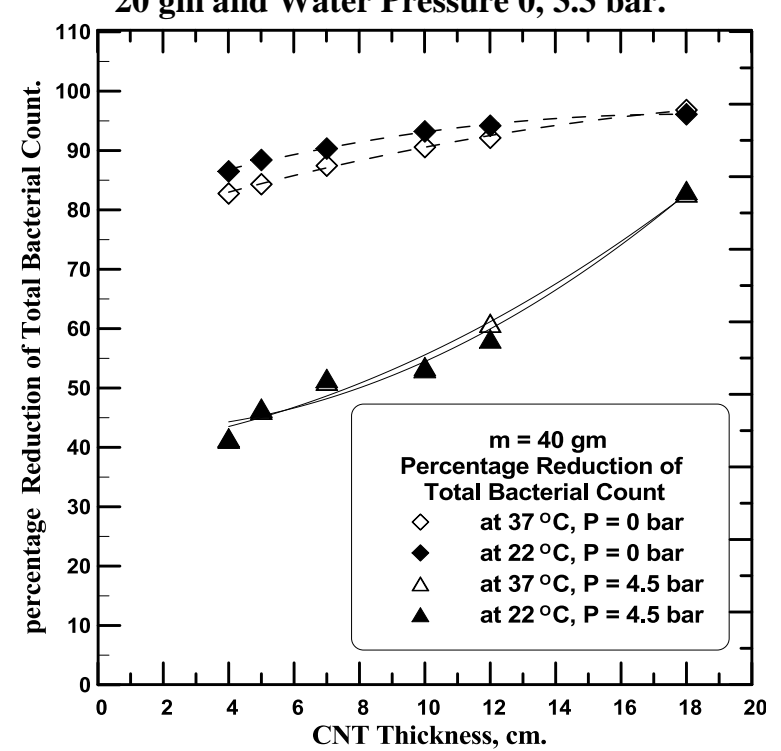

Figure (5b) Variation of Percentage Reduction of Total Bacterial Count with CNT Thickness for CNT mass = $40 \mathrm{gm}$ and Water Pressure 0, 4.5 bar.

The variation of percentage reduction of total coliforms count per $100 \mathrm{ml}$ versus CNT thickness for the different masses $(20,40 \mathrm{gm})$ of carbon nanotubes for the case in which the water exits under gravity or pressurized with the minimum pressure required to overcome the pressure drop through the CNT is shown in figures $(6 a-6 b)$. 


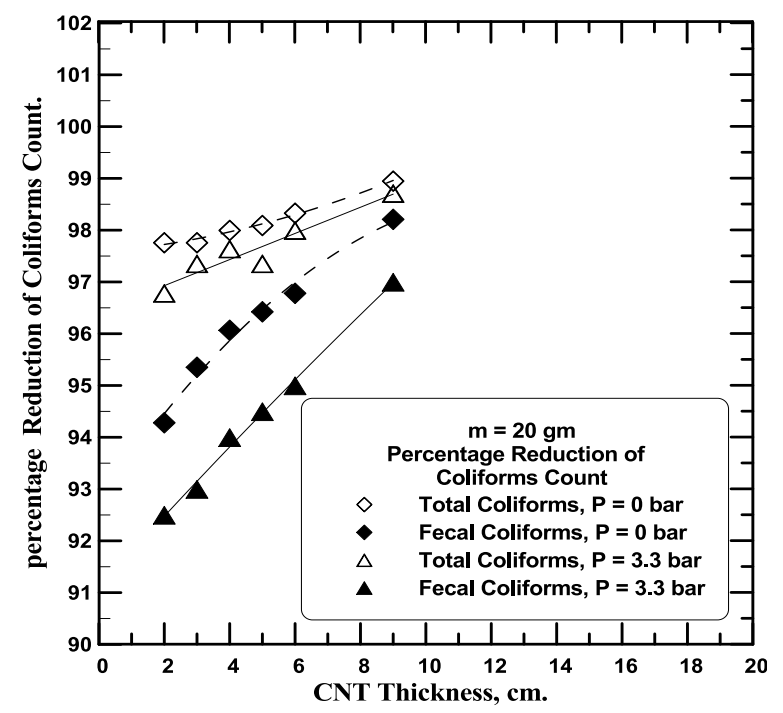

Figure (6a) Variation of Percentage Reduction of Coliforms Count with CNT Thickness for CNT mass = 20 gm and Water Pressure 0, 3.3 bar.

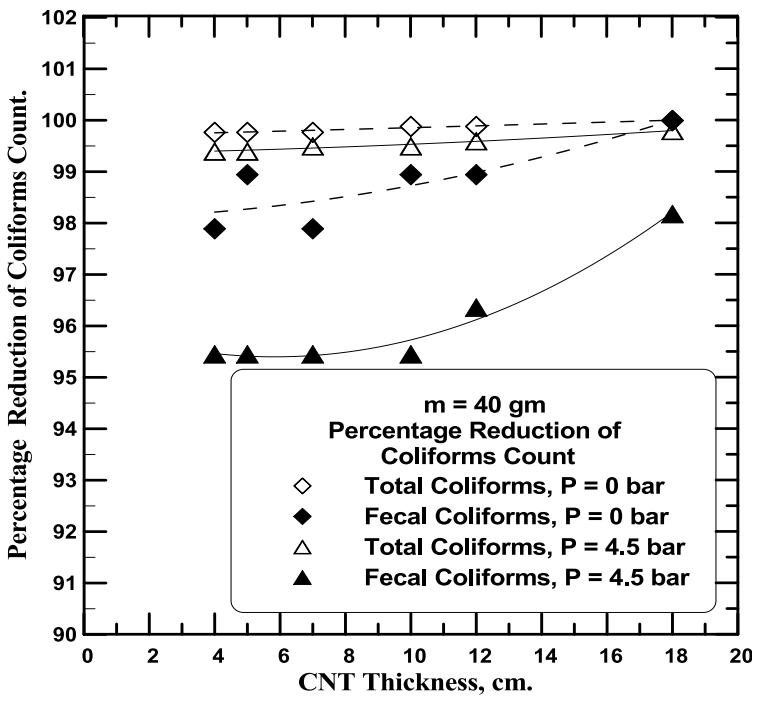

Figure (6b) Variation of Percentage Reduction of Coliforms Count with CNT Thickness for CNT mass $=20$ gm and Water Pressure 0, 3.3 bar.

It is observed that, the increase of the percentage reduction of total coliforms count is associated with increasing the thickness of the CNT. This may be a result of increasing the retained coliforms due to the longer time that the water takes to pass from the CNT for larger thickness.

The variation of percentage reduction of fecal streptococci count per $100 \mathrm{ml}$ versus CNT thickness for the different masses $(20,40 \mathrm{gm})$ of carbon nanotubes for the case in which the water exits under gravity or pressurized with the minimum pressure needed to overcome the pressure drop through the CNT is shown in the figures $(7 \mathrm{a}-7 \mathrm{~b})$. The curves plotted in these figures indicate that, increasing CNT thickness reveal an increase in percentage reduction of fecal streptococci count due to the increase of the adsorption capacity with the increase of CNT thickness. 


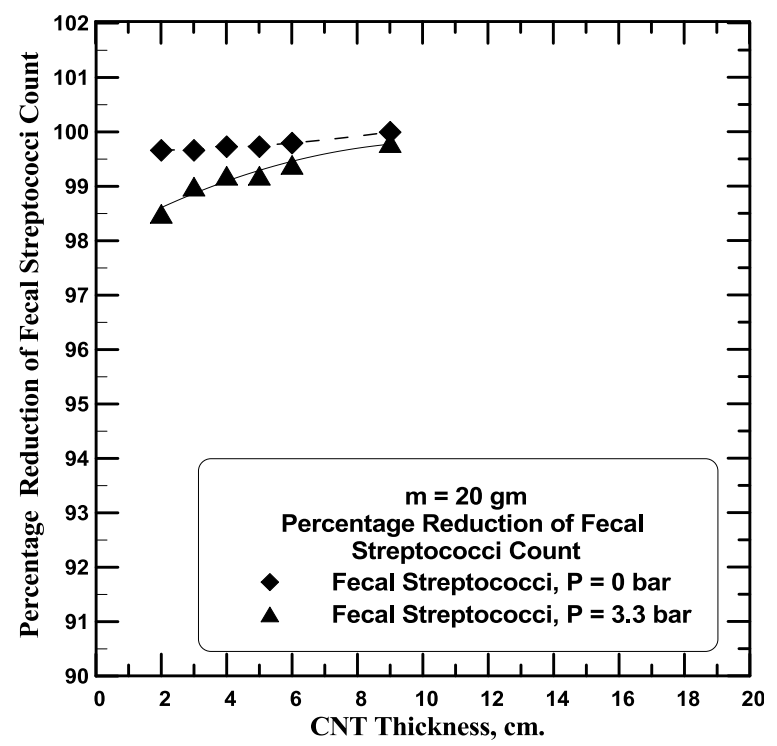

Figure (7a) Variation of Percentage Reduction of Fecal Streptococci Count with CNT Thickness for CNT mass $=20 \mathrm{gm}$ and Water Pressure 0, 3.3 bar.

\subsection{Effect of the Water temperature}

Figures $(8 \mathrm{a}-8 \mathrm{~d})$ show the variation of percentage reduction of total bacterial count per $1 \mathrm{ml}$ versus water temperature at two different samples temperatures of $37{ }^{\circ} \mathrm{C}$ and $22{ }^{\circ} \mathrm{C}$ for the two inner diameters $(40,54 \mathrm{~mm})$ and two different masses of CNTs (20, $40 \mathrm{gm})$. Two cases are investigated; a case in which the water exits under the gravity and the other case in which the water exit under the minimum pressure needed to overcome the pressure drop in the CNT.

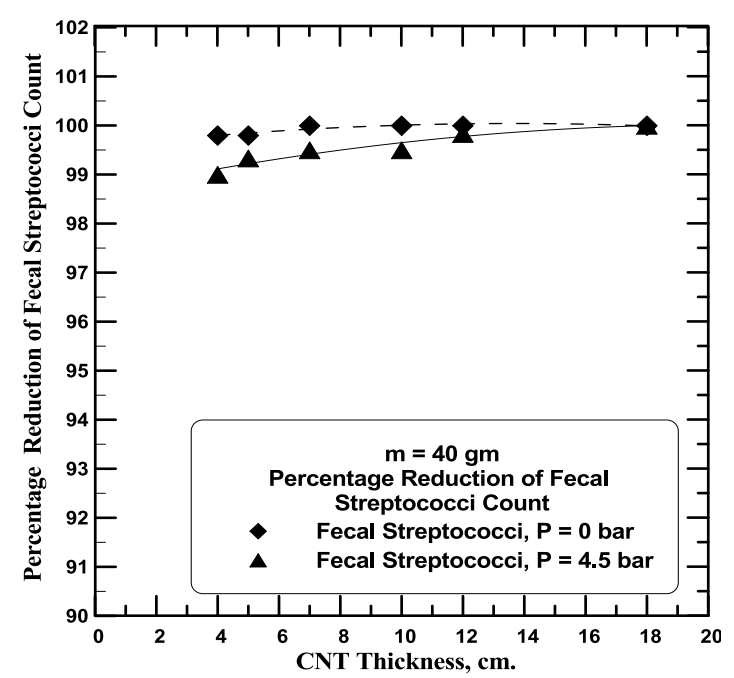

Figure (7b) Variation of Percentage Reduction of Fecal Streptococci Count with CNT Thickness for CNT mass $=40 \mathrm{gm}$ and Water Pressure 0, $4.5 \mathrm{bar}$. 


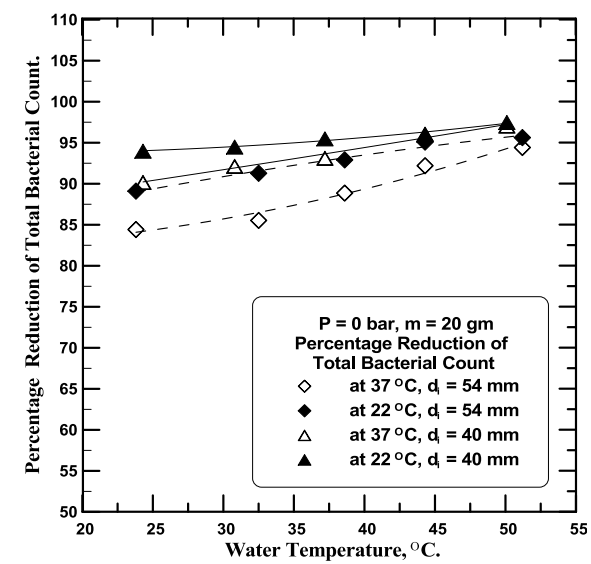

Figure (8a) Variation of Percentage Reduction of Total Bacterial Count with Inlet Water Temperature for Tube Inner Diameter $=(40,54 \mathrm{~mm})$, CNT mass $=20 \mathrm{gm}$ and $P=0$ bar.

It is observed that, the percentage reduction in total bacterial count for the both cases of the sample analysis at $37{ }^{\circ} \mathrm{C}$ and $22^{\circ} \mathrm{C}$, increase for higher water temperature. It may be attributed to, the rise in temperature of CNT which works to reduce the area of the holes located on the surface of the tube as a result of the expansion and contribute to enhance the retention of bacteria.

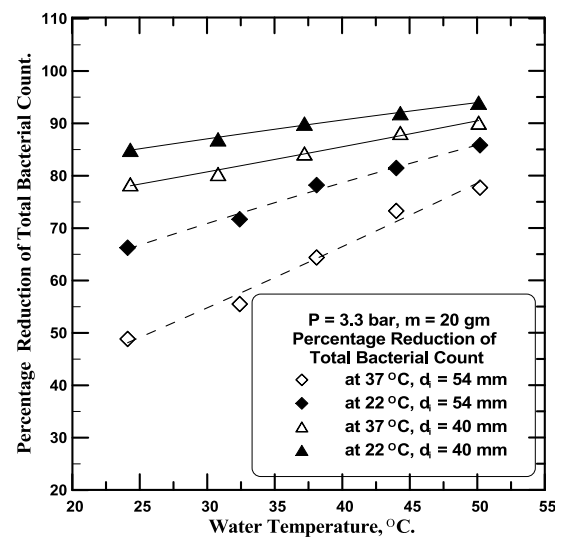

Figure (8b) Variation of Percentage Reduction of Total Bacterial Count with Inlet Water Temperature for Tube Inner Diameter $=(40,54 \mathrm{~mm}), \mathrm{CNT}$ mass $=20 \mathrm{gm}$ and $P=3.3 \mathrm{bar}$.

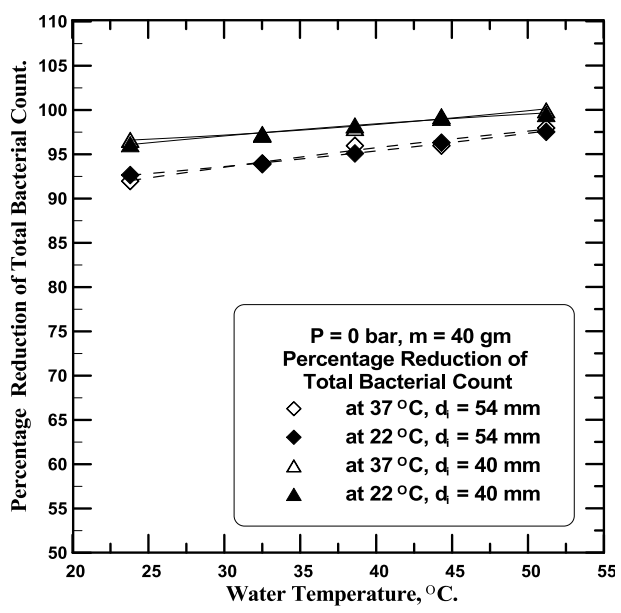

Figure (8c) Variation of Percentage Reduction of Total Bacterial Count with Inlet Water Temperature for Tube Inner Diameter $=(40,54 \mathrm{~mm}), \mathrm{CNT}$ mass $=40 \mathrm{gm}$ and $P=0$ bar. 


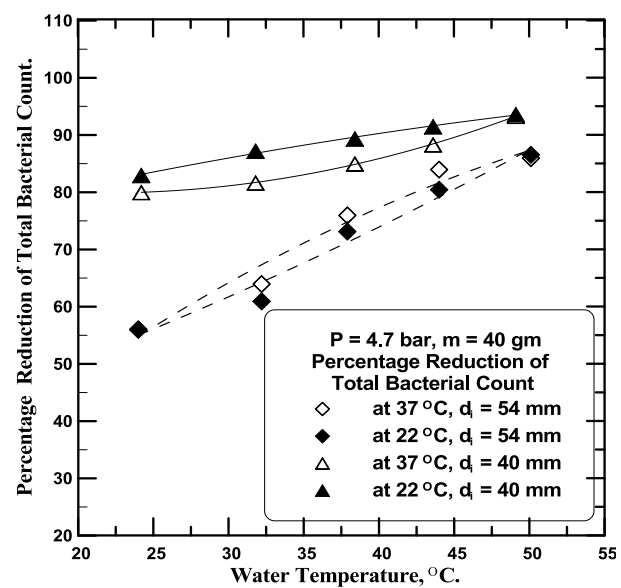

Figure (8d) Variation of Percentage Reduction of Total Bacterial Count with Inlet Water Temperature for

Tube Inner Diameter $=(40,54 \mathrm{~mm})$, CNT mass $=40 \mathrm{gm}$ and $P=4.7$ bar.

Figures $(9 a-9 d)$ represent the variation of percentage reduction of total coliforms count per 100 $\mathrm{ml}$ versus water temperature for the two inner diameters $(40,54 \mathrm{~mm})$ and two different masses of carbon nanotubes $(20,40 \mathrm{gm})$. Two cases are considered, a case in which the water exit under gravity and the other case in which the water exit under the minimum pressure needed to overcome the pressure drop in the CNT.

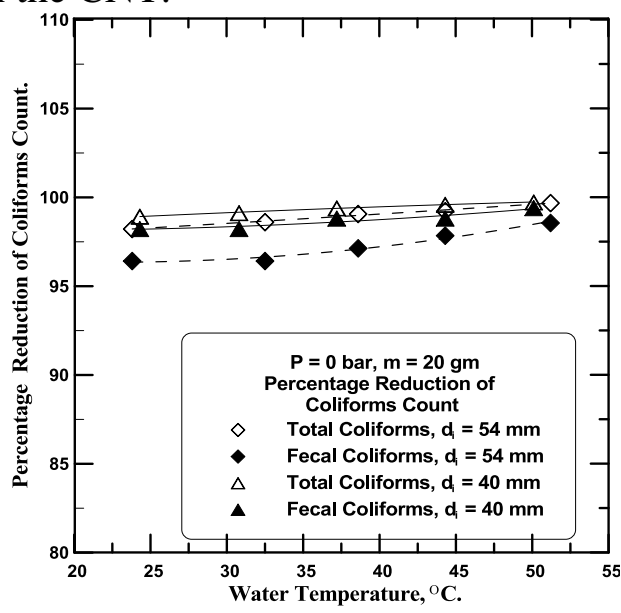

Figure (9a) Variation of Percentage Reduction of Coliforms Count with Inlet Water Temperature for Tube Inner Diameter $=(40,54 \mathrm{~mm}), \mathrm{CNT}$ mass $=20 \mathrm{gm}$ and $\mathrm{P}=0$ bar.

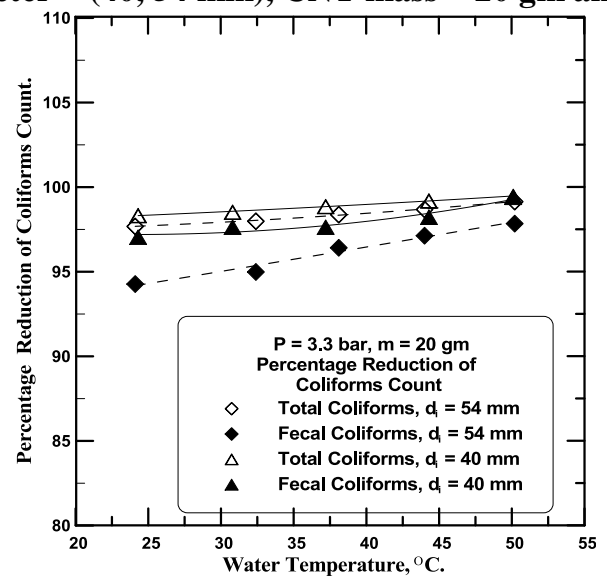

Figure (9b) Variation of Percentage Reduction of Coliforms Count with Inlet Water Temperature for Tube Inner Diameter $=(40,54 \mathrm{~mm}), \mathrm{CNT}$ mass $=20 \mathrm{gm}$ and $P=3.3 \mathrm{bar}$. 


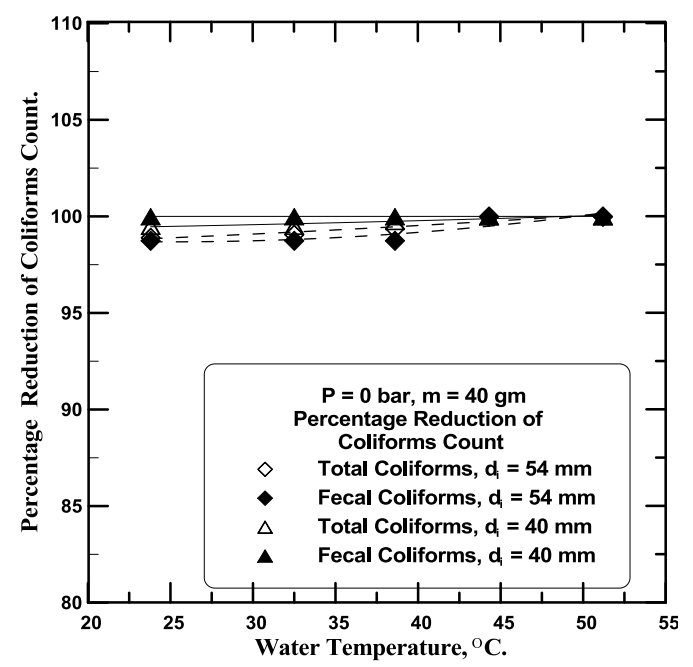

Figure (9c) Percentage Reduction of Coliforms Count Variation with Inlet Water Temperature for Tube Inner Diameter $=(40,54 \mathrm{~mm})$, CNT mass $=40 \mathrm{gm}$ and $P=0$ bar.

The curves presented in these figures indicated that, increasing water temperature results in an increase in the percentage reduction of coliforms count. This may be explained as follows; CNT expands at higher water temperature, this results in more adsorbed capacity of CNTs especially for low pressure. Such improvement in adsorption capacity may yield water with good quality to be used for human consumption.

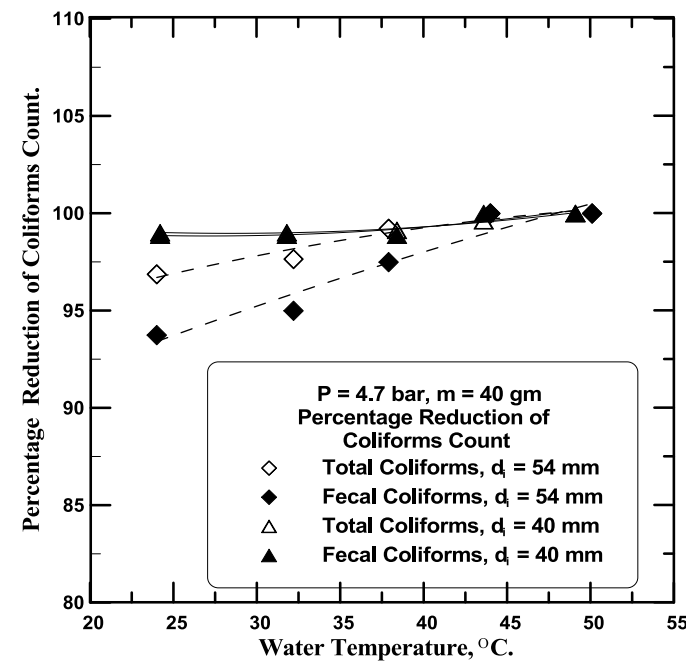

Figure (9d) Variation of Percentage Reduction of Coliforms Count with Inlet Water Temperature for Tube Inner Diameter $=(40,54 \mathrm{~mm}), \mathrm{CNT}$ mass $=40 \mathrm{gm}$ and $P=4.7$ bar.

The variation of percentage reduction of fecal streptococci count per $100 \mathrm{ml}$ versus water temperature for the two inner diameters $(40,54 \mathrm{~mm})$ and two different masses of carbon nanotubes $(20,40 \mathrm{gm})$ under two cases, a case in which the water exit gravity and under the minimum pressure required to overcome the pressure drop in the CNT is shown in figures (10a10d). 


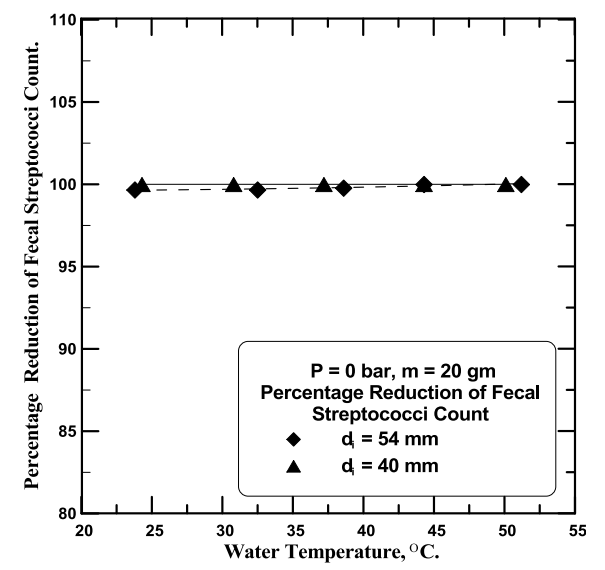

Figure (10a) Variation of Percentage Reduction of Fecal Streptococci Count with Inlet Water Temperature for Tube Inner Diameter $=(\mathbf{4 0}, 54 \mathrm{~mm})$, CNT mass $=20 \mathrm{gm}$ and $P=0$ bar.

It is observed that, the percentage reduction of fecal streptococci count slightly increases with the increase of the water temperature. This may be attributed to the same reasoning mentioned before. However, the adsorption capacity of CNTs for fecal streptococci is much better than coliforms because it is spherical shape.

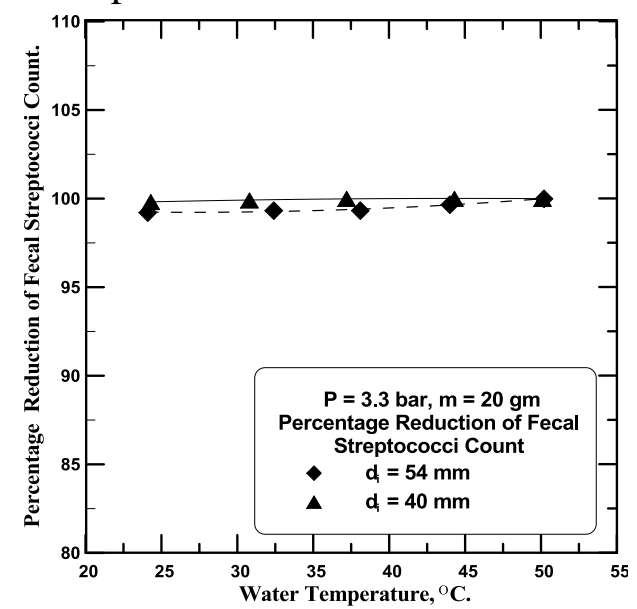

Figure (10b) Variation of Percentage Reduction of Fecal Streptococci Count with Inlet Water Temperature for Tube Inner Diameter $=(40,54 \mathrm{~mm}), \mathrm{CNT}$ mass $=20 \mathrm{gm}$ and $P=3.3 \mathrm{bar}$.

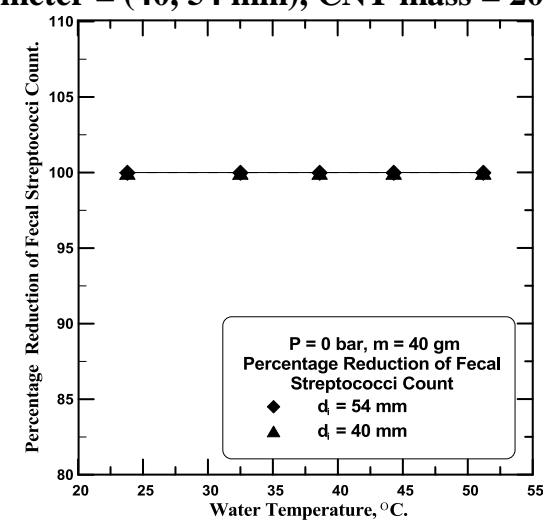

Figure (10c) Variation of Percentage Reduction of Fecal Streptococci Count with Inlet Water Temperature for Tube Inner Diameter $=(40,54 \mathrm{~mm})$, CNT mass $=40 \mathrm{gm}$ and $P=0$ bar. 
THE USE OF CARBON-NANOTUBES FOR REMOVAL OF BACTERIAL PATHOGENS FROM RIVER WATER

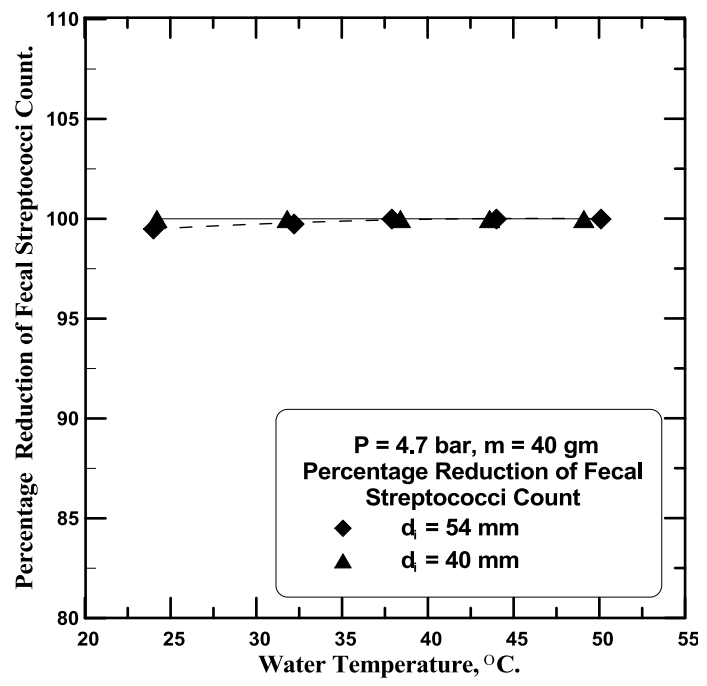

Figure (10d) Percentage Reduction of Fecal Streptococci Count Variation with Inlet Water Temperature for Tube Inner Diameter $=(40,54 \mathrm{~mm})$, CNT mass $=20 \mathrm{gm}$ and $P=4.7 \mathrm{bar}$.

\section{CONCLUSIONS}

The following conclusions could be deduced from the present work:

1- The percentage reduction in total bacterial count, total coliforms count, fecal coliforms count and fecal streptococci count decrease with the increase of water pressure.

2- The percentage reduction in total bacterial count, total coliforms count, fecal coliforms count and fecal streptococci count increase with the increase of the amount of CNT.

3- $\quad$ However, decreasing the tube diameter leads to increasing the thickness of CNT layer; thereby enhance the efficiency of the disinfection process.

4- The water temperature has significant effect on the percentage reduction in total bacterial count, total coliforms count, fecal coliforms count, and fecal streptococci count. The higher the water temperature, the higher the efficiency of the disinfection process.

5- $\quad$ The use of CNT in the disinfection processes gives effective results and could make raw water to be suitable for human consumption.

\section{REFERENCES}

[1] World Health Organization and UNICEF, 2012. Progress on Drinking Water and Sanitation: 2012 Update. Meeting the MDG Drinking Water and Sanitation Target. WHO/UNICEF, New York, NY.

[2] Shannon, M. A., Bohn, P. W., Elimelech, M., Georgiadis, J. G., Marinas, B. J., \&Mayes, A. M. (2008). Science and technology for water purification in the coming decades. Nature, 452(7185), (301$310)$.

[3] V.K. Gupta, I. Ali, T.A. Saleh, A. Nayak, S. Agarwal, Chemical treatment technologies for waste-water recycling - an overview, RSC Advances 2 (16) (2012), (6380-6388).

[4] Iijima, S., 1991. Helical microtubules of graphitic carbon. Nature 354 (6348), 56-58.

[5] Diallo, M.S., Savage, N., 2005. Nanoparticles and water quality. J. Nanoparticle Res. 7 (4-5), (325-330).

[6] Upadhyayula, V.K.K., Deng, S., Mitchell, M.C., Smith, G.B., 2009. Application of carbon nanotube technology for removal of contaminants in drinking water: a review. Sci. Total Environ. 408 (1), (1-13).

[7] Di, Z.C., Ding, J., Peng, X.J., Li, Y.H., Luan, Z.K., Liang, J., 2006.

Chromium adsorption by aligned carbon nanotubes supported ceria nanoparticles. Chemosphere $62(5),(861-865)$.

[8] Li, Y.H., Ding, Z., Luan, K., Di, Z.C., Zhu, Y.F., Xu, C.L., et al., 2003.

Competitive adsorption of $\mathrm{Pb}^{2+}, \mathrm{Cu}^{2+}$ and $\mathrm{Cd}^{2+}$ ions from aqueous solutions by multiwalled carbon nanotubes. Carbon 41 (14), (2787-2792). 
[9] Peng, X.J., Luan, Z.K., Ding, J., Di, Z.H., Li, Y.H., Tian, B.H., 2005.

Ceria nanoparticles supported on carbon nanotubes for the removal of arsenate from water. Mater. Lett. 59 (4), (399-403).

[10] Lu, C.S., Chung, Y.L., Chang, K.F., 2005. Adsorption of trihalomethanes from water with carbon nanotubes. Water Res. 39 (6), (1183-1189).

[11] Yan, H., Gong, A.J., He, H.S., Zhou, J., Wei, Y.X., Lü, L., 2006. Adsorption of microcystins by carbon nanotubes. Chemosphere 62 (1), (142-148).

[12] Brady-Estévez, A.S., Kang, S., Elimelech, M.A., 2008. Singlewalledcarbon nanotube filter for removal of viral and bacterial pathogens. Small 4 (4), (481-484).

[13] Brady-Estévez, A.S., Schnoor, M.H., Vecitis, C.D., Saleh, N.B., Ehmelech, M., 2010a. A multiwalled carbon nanotube filter: improving viral removal at low pressure. Langmuir 26 (18), (14975-14982).

[14] Brady-Estévez, A.S., Schnoor, M.H., Kang, S., Elimelech, M., 2010b. SWNT-MWNT hybrid filter attains high viral removal and bacterial inactivation. Langmuir 26 (24), (1915319158).

[15] Rahaman, M.S., Vecitis, C.D., Elimelech, M., 2012. Electrochemical carbon nanotube filter performance toward virus removal and inactivation in the presence of natural organic matter. Environ. Sci. Technol. 46 (3), (1556-1564)

[16] Li, Y-H., Ding, J., Luan, Z., Di, Z., Zhu, Y., Xu, C, Wu, D., Wei, B., (2003a). Competitive adsorption of $\mathrm{Pb}^{2+}, \mathrm{Cu}^{2+}$ and $\mathrm{Cd}^{2+}$ ions from aqueous solutions by multiwalled carbon nanotubes. Carbon 41, (278-2792).

[17] Lu, C., Su, F., (2007). Adsorption of natural organic matter by carbon nanotubes. Separation and Purification Technology 58, (113-121).

[18] Yuan, C. G., Zhang, Y., Wang, S., Chang, A., (2011). Separation and preconcentration of palladium using modified multi-walled carbon nanotubes without chelating agent. Microchim Acta 173, (361-367).

[19] Ihsanullah, A. Abbas, A. Al-Amer, T. Laoui, J. Al-Marri, Mu. S. Nasser, M. Khraisheh, M. Atieh, (2016). Heavy metal removal from aqueous solution by advanced carbon nanotubes: Critical review of adsorption applications. Separation and Purification Technology 157, (141161).

[20] Akhavan, O., Abdolahad, M., Abdi, Y., Mohajerzadeh, S., 2011. Silver nanoparticles within vertically aligned multi-wall carbon nanotubes with open tips for antibacterial purposes. J. Mater. Chem. 21 (2), (387-393).

[21] Lee, C., Baik, S., (2010). Vertically-aligned carbon nano-tube membrane filters with superhydrophobicity and superoleophilicity. Carbon 48 (8), (2192 - 2197).

[22] Schoen, D.T., Schoen, A.P., Hu, L.B., Kim, H.S., Heilshorn, S.C., Cui, Y., 2010. High speed water sterilization using one-dimensional nanostructures. Nano Lett. 10 (9), 3628-3632.

[23] Kang, S., Herzberg, M., Rodrigues, D.F., Elimelech, M., 2008a. Antibacterial effects of carbon nanotubes: size does matter. Langmuir 24 (13), (6409-6413).

[24] Kang, S., Mauter, M.S., Elimelech, M., 2008b. Physicochemical determinants of multiwalled carbon nanotube bacterial cytotoxicity. Environ. Sci. Technol. 42 (19), 7528-7534.

[25] Kang, S., Mauter, M.S., Elimelech, M., 2009. Microbial cytotoxicity of carbon-based nanomaterials: implications for river water and wastewater effluent. Environ. Sci. Technol. 43 (7), (2648-2653).

[26] Brady-Estévez, A.S., Nguyen, T.H., Gutierrez, L., Elimelech, M., 2010c. Impact of solution chemistry on viral removal by a single-walled carbon nanotube filter. Water Res. 44 (13), (37733780).

[27] J.Kim, Ha Kim, Jieun Kim, S. Lee, H. Park, (2016). A nanofilter composed of carbon nanotube-silver composites for virus removal and antibacterial activity improvement. Jor. Of Env. Science 42 (275-283). 